\title{
Unequal at the Starting Line: Creating Participatory Inequalities across Generations and among Groups
}

\section{Citation}

Verba, Sidney, Nancy Burns, and Kay L. Schlozman. 2003. Unequal at the starting line: Creating participatory inequalities across generations and among groups. The American Sociologist 34(1-2): 45-69.

\section{Published Version}

http://dx.doi.org/10.1007/s12108-003-1005-y

\section{Permanent link}

http://nrs.harvard.edu/urn-3:HUL.InstRepos:2643014

\section{Terms of Use}

This article was downloaded from Harvard University's DASH repository, and is made available under the terms and conditions applicable to Other Posted Material, as set forth at http:// nrs.harvard.edu/urn-3:HUL.InstRepos:dash.current.terms-of-use\#LAA

\section{Share Your Story}

The Harvard community has made this article openly available.

Please share how this access benefits you. Submit a story.

\section{Accessibility}




\title{
Unequal at the Starting Line: Creating Participatory Inequalities across Generations and among Groups
}

\author{
Sidney Verba, Nancy Burns, and Kay Lehman Schlozman
}

We investigate how inequalities in political participation are shaped across generations by considering the influence of family background-in particular, parents' education and political involvement—on political participation. We pursue this issue, first, for individuals, investigating the effects of parental characteristics on the participatory profile of their offspring. Then, we use what we have learned to understand how group differences in political participation-between women and men and among Latinos, African Americans, and Anglo Whites-are rooted in the legacy of class and political background and in experiences throughout the life cycle.

Americans are much more comfortable with inequalities of result when it comes to economics than when it comes to politics. According to the American Dream, so long as we are equal at the starting line, we expect and accept the inequalities of income and wealth that result from individual differences in talent and industry. In contrast, we expect not only that citizens possess equal rights on the level playing field of democracy but that public officials will respond equally to all. ${ }^{1}$ Thus, while the transmission of economic inequality across generations would constitute a violation of the ideology of the American Dream, the transmission of political inequality across generations would constitute a double infringement: transgressing not only the principle of equality of opportunity but also the principle of equality of outcome among citizens.

That Americans are quite unequal in occupation and income is hardly news. Furthermore, it is well known that, contrary to the promise of the American Dream, we are not equal at the starting line when it comes to occupational and economic success. Numer-

Sidney Verba is the Carl H. Pforzheimer University Professor at Harvard University and Director of the Harvard University Library, Kay Lehman Schlozman is the J. Joseph Moakley Professor of Political Science at Boston College, and Nancy Burns is the Henry Simmons Frieze Professor of Political Science at the University of Michigan and Principal Investigator, American National Election Study. They are the co-authors of The Private Roots of Public Action: Gender, Equality, and Political Participation (Cambridge: Harvard University Press, 2001) which was the co-winner of the Victoria Schuck Award of the American Political Science Association for the best book on gender and politics of its year.

Verba, Burns, and Schlozman 
ous sociological studies have established that the race does not start anew with each generation: instead, parents are able to pass on class status to their offspring and, thus, socio-economic stratification persists from generation to generation. ${ }^{2}$ Of course, as demonstrated by SES differences between adult siblings, the transmission of socio-economic status from parent to child is far from perfect. Nevertheless, the transmission of socioeconomic advantage across generations results in persistent class differences that have roots in the past.

What about in politics? Contrary to Americans' normative commitment to political equality is the well-established fact of political inequality among citizens: individuals and social groups differ significantly in the extent to which they take part in political life, and these differences have consequences for who gets what from the government. Systematic research has demonstrated over and over the strong links between socio-economic status-occupation, income and, especially, education - and citizen political participation. ${ }^{3}$ The association between SES and political activity has ramifications for disparities in participation among other politically relevant groups. The participatory differences among racial and ethnic groups can be fully explained-and the participation gap between men and women can be partially explained-by group differences in SES. ${ }^{4}$

\section{The Legacy of the Family for Political Participation}

Are political inequalities, like economic inequalities, bequeathed from one generation to the next? When, as it did in 2000, a presidential contest pits the son of a former senator against the son of a former president, it is hard to doubt that family inheritance plays a role in the achievement of elite political status. Do analogous processes operate for ordinary citizens? Are the children of politically active parents more likely to be active than are those from less active families? In this paper, we focus on the largely unstudied issue of the persistence of inequality in political activity and its roots in processes of intergenerational transmission.

In explaining participation, political scientists currently tend to focus on proximate causes - in particular, the characteristics of individuals and the nature of their political and social contexts. At one point in the past, however, political scientists paid a great deal of attention to the potential influence of early experience on the political behavior of adults. However, the concern with the legacy of the past intrinsic to studies of political socialization was soon eclipsed, in part because of the difficulty in drawing inferences for the political commitments and behavior of adults from studies, even sophisticated and well-designed studies, of children. ${ }^{5}$

Both the inheritance bequeathed by the family and the significance of various family characteristics-among them, social class-figure importantly in this earlier literature. ${ }^{6}$ In spite of the focus on the consequences for adult citizens of the social class of the family of origin, however, the emphases in the early socialization studies do not speak directly to our concerns. First, the legacy of the family is framed mostly in terms of the substance of politics: the absorption of political information and political orientations-in particular, party identification - at home. ${ }^{7}$ In addition, extensive social class differences in children's political information and orientations are explained in terms of subcultural differences between SES groups with respect to such aspects of family dynamics as the autonomy permitted to children, the relative emphasis placed on obedience, and the encouragement of discussion of controversial matters. ${ }^{8}$ From these social class differences in family life and child-rearing patterns, inferences are drawn about the presumed future capacity to take part in politics. 
While it is quite reasonable to expect that children and adolescents who are encouraged to be independent and to contribute to family discussions will develop into active citizens, the lack of attention to the income and educational advantages that accrue to those who grow up in high-SES families, and the future participatory payoff of those income and educational advantages, is noteworthy.

In this paper we link two well-known regularities- the transmission of SES from generation to generation and the significance of SES for political activity-to demonstrate an alternative mechanism by which the family of origin leaves a legacy for the political participation of future citizens. Thus, parents who are advantaged in SES terms - who have higher levels of education, income, and occupational status - pass on those socio-economic advantages to their offspring which are, in turn, translated into political activity in the next generation. Because it is the single most substantial and most multi-faceted influence on political activity, we focus on education as the primary vehicle by which socio-economic status acts to transmit political activity across generations. Not only does education have a direct impact on political participation but level of education affects the acquisition of nearly all the other factors that facilitate participation: the well-educated are more likely to earn high incomes on the job; to develop civic skills at work, in non-political organizations and, to a lesser extent, in church; to be in social networks through which requests for political activity are mediated; and to be politically interested and knowledgeable. ${ }^{10}$

We consider as well another mechanism by which parents might influence the participation of their offspring, a political path. Just as parents can enrich their children financially by leaving them money, so can politically active parents leave a legacy of political involvement to their children by exposing them to politics. A politically rich home environment-in which politically active parents act as role models and children are exposed to political discussions and other political stimuli-fosters later political involvement. Because welleducated parents are likely also to be politically active, the SES and political paths are connected.

In addition, we expect that the legacy of parents' education operates in other ways about which, because we use recall data collected from adults, we were unable to ask. For example, all things equal, having parents who were politically and socially well connected or who filled the house with books, newspapers, and periodicals would, presumably, have consequences for future political participation. Moreover, unmeasured aspects of child-rearing that are discussed in the earlier literature on socialization - for example, emphasis on obedience or encouragement of autonomy and independence-might influence future political activity.

We will show that these two processes of intergenerational transmission of political activity — as the direct result of coming of age in a politically stimulating environment or as the indirect result of the transmission of socio-economic status across generations-operate, separately and in interaction one with the other. The distinction between the two processes is important for our understanding not only of the sources of political action but also of the way political inequalities might be ameliorated or exacerbated by changes in the distribution of income and education or by changes in politics itself.

Politics is not just about individuals; it is also about groups. Political competition usually involves contention between groups and the outcomes usually impose costs and confer benefits on groups. Hence, it matters not only whether some individuals inherit advantages for future political involvement from their parents, but also whether these intergenerational processes result in participatory inequalities across politically-relevant categories of individuals. ${ }^{11}$ Thus, we expand our analysis of the way in which political participation is shaped by parents' SES and political characteristics to focus on the roots of group differences in 
political participation in the legacy of the past. In considering how participatory inequalities among groups are shaped across generations, we consider three bases of political contestation-perhaps the significant bases of contestation in America-class, race or ethnicity, and gender. That is, we ask: to what extent are class, racial or ethnic, and gender differences in political activity the result of where group members were early in life?

\section{From Generation to Generation: Participation and Education}

We begin our analysis with basic bivariate data. ${ }^{12}$ To begin with, there is a statistically significant relationship between respondents' political activity as adults and their reports about the political environment at home when they were adolescents-whether their mothers and fathers were politically active and whether there was political discussion at home. ${ }^{13}$ If we stratify respondents on the basis of the political richness of the home environment, we find that 43 percent of respondents in the bottom quartile on the home political environment scale undertake some political activity other than voting in contrast to 69 percent of the respondents in the top quartile of the scale. Although these data do not establish why, they make clear that the politically richer the home environment, the more likely an adult is to undertake some political activity other than voting. ${ }^{14}$ This relationship is even more dramatic when we consider the volume of activity rather than the proportion of respondents who undertook some activity other than voting. The vote is unique among political acts in that there is mandated equality in political input: we each get only one. In contrast, for other kinds of activity, those who have the will and the wherewithal can multiply their political input. Using dollars and hours as the metric, we found that the 28 percent of respondents in the lowest category in terms of home political environment produce only 10 percent of total hours given to politics and 5 percent of the total dollars contributed to political campaigns and causes. In contrast, the 22 percent of respondents in the top category in terms of home political environment produce 40 percent of total hours and 55 percent of the total dollars.

While politically active parents are more likely to have politically active children, welleducated parents are even more likely to have well-educated children. Those whose parents were in the top quartile of education are nearly three times as likely to be high school graduates as are those whose parents were in the bottom quartile. ${ }^{15}$ In light of the relationship between education and political activity, we need to complete the circle by considering the relationship between respondents' exposure to political stimuli as an adolescent and their parents' educational attainment. Well-educated parents are more likely to provide a rich political environment. Compared to respondents whose parents were in the lowest educational group, respondents whose parents were in the top educational group are more than twice as likely to have had parents in the top quartile with respect to the richness of the political environment they provided. ${ }^{16}$

In order to understand the processes by which intergenerational transmission shapes political activity, we turn to multivariate analysis. Table 1, which presents an OLS regression predicting scores on an eight-point scale summarizing the number of political activities the respondent has undertaken, contains several kinds of explanatory variables. First are measures of characteristics at birth: gender, race or ethnicity, and parents' education. Next are two factors that reflect experiences while growing up: the respondent's own education and exposure to politics at home, both of which are consequences, in part, of parents' education. In addition are four measures of participatory factors acquired in adulthood: family income, the respondent's own earnings from employment, civic skills, and requests for po- 
Table 1

Predicting Political Activity

Ordinary Least Squares Regression ${ }^{\mathrm{a}}$

\begin{tabular}{lc}
\hline Explanatory Variable & $\begin{array}{c}\text { Coefficient } \\
(\text { s.e. })\end{array}$ \\
\hline Parent' Education & $.61^{* * *}$ \\
DIRECT CONSEQUENCES OF PARENTS' EDUCATION & $(.18)$ \\
Respondent's Education & $1.32^{* * *}$ \\
Politics at Home & $(.12)$ \\
RESOURCES GATHERED LATER IN LIFE & $.82^{* * *}$ \\
Family Income & $(.14)$ \\
Respondent's Own Earnings & $2.22^{* * *}$ \\
Civic Skills & $(.31)$ \\
Recruitment & -.43 \\
GENDER, RACE, AND ETHNICITY & $(.39)$ \\
Woman & $1.47^{* * *}$ \\
Black & $(.16)$ \\
Latino & $2.07^{* * *}$ \\
N & $(.19)$ \\
\hline
\end{tabular}

${ }^{a}$ The equation also includes age, age over 65 , and a constant term.

${ }^{*}$ Coefficient significant at $\mathrm{p}<.05$.

** Coefficient significant at $\mathrm{p}<.01$.

*** Coefficient significant at $\mathrm{p}<.001$.

litical activity originating in the major non-political institutions of adult life-the workplace, non-political organizations, and religious institutions-factors that, as we shall see, are influenced by parents' education. ${ }^{17}$ Table 1 begins to demonstrate how the consequences of parental education influence political participation. The factors that result directly from parental education, respondent's education and politics at home, matter a good deal. Likewise, the factors that, we shall see, come more indirectly from parents' education-family income and civic skills developed in and requests for activity originating in adult institutions-are also significant. ${ }^{18}$ Thus, these data offer evidence that political participation is transmitted from generation to generation.

In Table 2 we elaborate the multiple processes through which parental education affects the respondent's political participation by showing the paths by which intergenerational transmission operates. ${ }^{19}$ For the sample as a whole, the average number of political acts is 2.11. As shown in the table, about one quarter of the average person's level of activity (.53 of those 2.11 acts) derives from the various effects of parental education. While the nature of 
Table 2

How Much Participation Comes from the Effects of Parents' Education?

\begin{tabular}{ll}
\hline & Consequence \\
\hline Effects through political stimuli & $.06 \mathrm{act}$ \\
$\quad$ Politics at home & $.20 \mathrm{act}$ \\
Effects through socio-economic processes & $.06 \mathrm{act}$ \\
$\quad$ Respondent's education & $.06 \mathrm{act}$ \\
$\quad$ Family income & $.02 \mathrm{act}$ \\
$\quad$ Civic skills & $.13 \mathrm{act}$ \\
$\quad$ Recruitment & $.53 \mathrm{act}$ \\
Additional effects of parents' education & (or $25 \%$ of the average number of acts, 2.11) \\
$\quad$ on participatory acts &
\end{tabular}

our sample and the uncertainty in the measures of the explanatory and the dependent variables imply that we should not overestimate the specificity of that particular number (or any other number in the table), its magnitude is worth noting. While political activity is not fully determined at birth, a significant portion is transmitted from generation to generation. That family background is not the whole story is hardly surprising. Sibling studies have long demonstrated the variation in adult behavior even among those who share genes and environment. Nevertheless, family background exercises an important influence on adult political activity.

Considering these data more closely, we see that one part of the effect of parents' education on activity - a little over one-tenth of the overall impact-is explicitly political. Welleducated parents tend to provide a rich political environment at home, and respondents who have been exposed to politics at home while growing up are more politically active as adults. ${ }^{20}$ Even more substantial than the impact of the political environment at home, however, are the effects of socio-economic processes. The single most important of these processes derives from the expected strong relationship between parents' education and that of their offspring and the consequences, in turn, of respondent's education for political participation. In addition, parents' education influences the respondent's political participation through its consequences for subsequent life experiences outside politics: family income and civic skills exercised and requests for activity in non-political institutions-on the job, in non-political organizations, and at church. Lastly, additional processes that cannot be specified with any precision account for roughly one-quarter of the effect of parental education on political activity. ${ }^{21}$ These estimates of parental effects are not insubstantial in light of the number of other variables included in the analysis.

In data not shown, we took the analysis one step further. For the eight-point scale measuring overall political activity, we substituted two measures of the volume of participation: the amount of time donated to political activity; and the amount of money donated to campaigns and other political causes. Our results reinforce the understanding that there are two different mechanisms of intergenerational transmission. The impact of parents' education that runs through its influence on the political environment at home is manifest for the number of hours given to politics, but not for the number of dollars. That is, growing up in a politically stimulating home enhances the future propensity to give time to politics, but has no effect when it comes to giving money. For making political contributions, the single 
Table 3

Activity and Income: Intergenerational Transmission

Ordinary Least Squares Regression ${ }^{\mathrm{a}}$

\begin{tabular}{|c|c|c|}
\hline Explanatory Variable & $\begin{array}{l}\text { Predicting } \\
\text { Political Activity } \\
\text { Coefficient } \\
\text { (s.e.) }\end{array}$ & $\begin{array}{c}\text { Predicting } \\
\text { Respondent's Income (Logged) } \\
\text { Coefficient } \\
\text { (s.e.) }\end{array}$ \\
\hline Parents' Education & $\begin{array}{c}.10^{* *} \\
(.04)\end{array}$ & $\begin{array}{l}.20^{* * *} \\
(.06)\end{array}$ \\
\hline \multicolumn{3}{|c|}{ DIRECT CONSEQUENCES OF PARENTS’ EDUCATION } \\
\hline Respondent's Education & $\begin{array}{l}.40^{* * *} \\
(.03)\end{array}$ & $\begin{array}{l}.60^{* * *} \\
(.05)\end{array}$ \\
\hline Politics at Home & $\begin{array}{l}.15^{* * *} \\
(.03)\end{array}$ & $\begin{array}{c}.01 \\
(.05)\end{array}$ \\
\hline \multicolumn{3}{|l|}{ CONTROLLING FOR } \\
\hline Hours of Employment & $\begin{array}{c}.09^{*} \\
(.04)\end{array}$ & $\begin{array}{l}1.26^{* * *} \\
(.06)\end{array}$ \\
\hline \multicolumn{3}{|c|}{ GENDER, RACE, AND ETHNICITY } \\
\hline Woman & $\begin{array}{l}-.03^{*} \\
(.01)\end{array}$ & $\begin{array}{l}-.22^{* * *} \\
(.02)\end{array}$ \\
\hline Black & $\begin{array}{l}.00 \\
(.02)\end{array}$ & $\begin{array}{l}-.08^{*} \\
(.03)\end{array}$ \\
\hline Latino & $\begin{array}{l}-.05^{*} \\
(.02)\end{array}$ & $\begin{array}{l}-.05 \\
(.04)\end{array}$ \\
\hline $\mathrm{N}$ & 2517 & 2517 \\
\hline
\end{tabular}

${ }^{a}$ The equation also includes age, age over 65 , and a constant term.

${ }^{*}$ Coefficient significant at $\mathrm{p}<.05$.

** Coefficient significant at $\mathrm{p}<.01$.

*** Coefficient significant at $\mathrm{p}<.001$.

most important factor is family income, and parents' education has direct consequences for family income-above and beyond its effect on respondents' education. ${ }^{22}$ Thus, these data strengthen our conclusion that, when it comes to political activity, we are not equal at the starting line. Instead, parents' educational attainment reaches across generations to influence in many ways the political participation of their offspring.

It is interesting to compare the effect of parental education on the intergenerational transmission of political activity with the effect of parental education on the transmission of socio-economic status (as measured by income). In Table 3 we present OLS regressions that permit us to compare the factors that predict (as in Table 1) respondents' political activity as well as their income from their jobs. We focus exclusively on the employed and change the specification somewhat from that used in Table 1. Since they derive in part from the jobs that produce the individual's income, we omit family income, skills, and recruitment as independent variables. Because the number of hours worked is strongly related to income from a job, we add it to the independent variables. Considering the parental legacy, we see that, as expected, parental education is significantly related both to respondent's political activity and to respondent's job income. A stimulating political environment at home as a teenager, however, has consequences for later political activity, but not for later job income. These data lend credibility to the fact that there is a politics-specific intergenerational connec- 
tion that links a politically rich home environment to later political involvement but not to subsequent job success.

Since the metrics are different, we must be cautious in comparing the processes of transmission of political participation and economic success across the generations. It seems, however, that parents' education plays a bigger role in shaping their children's job income than their political activity. Still, the striking finding in Table 3 is the overall resemblance between political activity and income with respect to the influence of a parental legacy. Equality of opportunity obtains for neither politics nor markets. In neither domain is there equality at the starting line. The characteristics of parentstheir education when it comes to income, their education and political involvement when it comes to political activity—give some a head start.

\section{Class Background and Group Differences}

When individual inequalities in political participation aggregate in such a way as to produce disparities in activity among politically relevant groups, the inequalities in political activity are especially consequential. There are, in fact, group differences in political activity as measured by the eight-point participation scale with men somewhat more active than women and Anglo Whites somewhat more active than African Americans and considerably more active than Latinos. ${ }^{23}$ We now seek to extend our exploration by assessing the extent to which such group differences in participation have their roots in these processes of intergenerational transmission. ${ }^{24}$ Education is, once again, crucial to our argument, and we focus on education as we consider the way in which group differences in early experiences create inequalities across groups in political activity. The various transmission paths from parental education to political activity are the same as those outlined for the individual effects, but there are additional considerations in dealing with group differences.

\section{The Transmission of Education across Generations: An Outcomes Analysis}

For a fuller understanding of the several possible processes of transmission from generation to generation that might operate to create group differences in participation, we build on and extend our earlier analyses by turning to an "outcomes" analysis. ${ }^{25}$ Our approach requires attention to several features of the process that links early experiences to group differences in adult political activity. We begin by differentiating between the level and effect of various factors that facilitate political activity. By level, we refer to the average amount of a participatory factor commanded by members of a group. For a human attribute that we would expect to have no relationship to political participation — say, physical strength-a group difference in the attribute, even if substantial, would have no participatory consequence. For factors known to be strongly associated with political participation — say, family income- a group difference in the level of the attribute would be crucial. Given our concern with processes of intergenerational transmission, we shall be concerned, in particular, with disparities among groups in the average level of parental education and in the level of home political stimulation. With respect to effect, we refer to the extent of the boost given to the dependent variable, in this case political activity, by a given change in a particular factor. There is no reason to assume that the effects of participatory factors are uniform across groups. To illustrate the possibility of group-based differences in rates of conversion, consider an extreme example, African Americans in the South under segregation. Because Blacks were prevented by law, custom, and violence from voting or otherwise taking part in 
Table 4

Educational Attainment and Political Involvement across the Generations ${ }^{\mathrm{a}}$

\begin{tabular}{lccccc}
\hline & Men & Women & $\begin{array}{c}\text { Anglo } \\
\text { Whites }\end{array}$ & Blacks & Latinos \\
\hline A. EDUCATION & & & & & \\
$\quad \begin{array}{l}\text { Parents' education } \\
\quad \text { Respondent's education }\end{array}$ & .23 & .22 & .23 & $.16^{\mathrm{b}}$ & $.13^{\mathrm{b}}$ \\
B. POLITICAL ACTIVITY & .42 & $.38^{\mathrm{c}}$ & .41 & $.34^{\mathrm{b}}$ & $.29^{\mathrm{b}}$ \\
$\quad \begin{array}{l}\text { Parents' political involvement } \\
\text { Respondent's political activity }\end{array}$ & .24 & .24 & .25 & .23 & $.16^{\mathrm{b}}$ \\
\hline
\end{tabular}

${ }^{a}$ All variables have been rescored to take on values from 0 to 1 .

${ }^{\mathrm{b}}$ Significantly different from Anglo Whites at $\mathrm{p}<.01$.

c Significantly different from men at $\mathrm{p}<.01$.

${ }^{d}$ Average score on a scale including mother's political activity, father's political activity, and political discussions at home (all measured at age 16).

politics, the relationship between education and participation in the Jim Crow South must have been very different for Blacks and Whites.

We start our consideration of this analytical chain by examining, for the two generations, levels of education and political activity within each of five groups: two gender groups and three groups defined by their race or ethnicity, Anglo Whites, African Americans, and Latinos. With respect to education, Table 4 shows two distinct patterns. Since boys and girls are born more or less randomly into families, there is no real difference in the educational attainment of the parents of the men and women in the sample. ${ }^{26}$ Nevertheless, whether because they had more limited educational aspirations or because they received more limited support and encouragement from their parents and teachers, women end up, on average, somewhat less well-educated than men are. With respect to race or ethnicity, the pattern is quite different. African Americans and Latinos begin with an educational deficit, which is then reproduced. ${ }^{27}$ That is, the parents of Anglo White respondents in our sample have relatively high levels of educational attainment as do the Anglo-White respondents themselves. The contrast between the two sets of groups is noteworthy. While the gender gap in education is created during men's and women's lifetimes, educational disparities among groups defined by their race or ethnicity have intergenerational origins.

We should pause to note that these data, which are for the adult population, represent the accumulation of previous decades of disparities among groups in educational attainment and do not allow us to extrapolate into the future. Among younger cohorts there has been a diminution of the education gap between women and men and between African Americans and Anglo Whites, though not between Latinos and Anglo Whites. Women, whose rates of high school graduation have long compared favorably to men's, are now more likely to graduate from college than men are. Among 25-to-29 year olds, the ratio of the percentage of African-Americans with a high school diploma to the percentage of Whites with a high school diploma was .30 in 1940, .66 in 1974, and .93 in 2000..$^{28}$ In contrast, the ratio of Latino to Anglo White high school graduation percentages has diminished in recent decades; in 1974, it was .67; in 2000, it was .59. ${ }^{29}$ Thus, as time goes by, we would expect a decrease in the disparity between Anglo Whites and African Americans-but not necessarily between Anglo Whites and Latinos-in the parental educational circumstances in which children come of age. 
Table 4B presents information for these groups about the other aspect of the legacy of early home life, exposure to political stimuli. It tells a similar story. With respect to political exposure, there is no appreciable difference between the homes in which girls and boys come of age. ${ }^{30}$ In contrast, there are racial and ethnic differences in the political richness of the home environment. Anglo Whites are considerably more likely than Latinos and slightly, though not significantly, more likely than Blacks to grow up in a politically stimulating home.

\section{Calculating Outcomes Based on Level and Effect}

We now undertake what we call an "outcomes analysis" to demonstrate the processes by which group differences in levels of parental endowments and the effects of parental endowments create group differences in political participation. To take possible differences in effect into account, we analyze the processes of transmission separately for each of the groups. Though we conduct our analyses separately for each group, we present the results of those analyses in terms of the extent to which the process in question augments or diminishes group differences in the relevant outcome. Since there are multiple processes, the analysis proceeds in stages. As discussed earlier, parents' education has an impact on respondent's

political activity through a socio-economic path and through a political path, each of which needs to be considered. By the end we are able to summarize how various transmission processes work together to influence participatory inequalities between women and men, between Anglo Whites and African Americans, and between Anglo Whites and Latinos.

Table 5A reports data on the implications of group differences in both level and effect for the first stage of a chain that leads to group differences in political activity: the linkage between group differences in parental education and respondent's education. The table contains a lot of numbers. Let us pause to explain how to read the table. The first row of Table $5 \mathrm{~A}$ repeats numbers from Table 4 and shows the average level of parents' education for the groups we are comparing. ${ }^{31}$ We report, as well, whether these levels are statistically different from one another. As mentioned, men and women do not differ significantly in the ageadjusted education of their parents. However, Anglo Whites do differ significantly from Blacks and from Latinos with respect to parents' educational background.

The second row of numbers contains the unstandardized regression coefficients from OLS regression equations, conducted separately for each group, that predict the respondent's education. ${ }^{32}$ These coefficients measure the effect on respondent's education of moving from the lowest to the highest category of the parental education scale. For each group, the impact of parents' education on that of their offspring is substantial. Moreover, the effect is statistically uniform across groups: there are no significant group differences in the magnitude of that impact. ${ }^{33}$

The next set of numbers shows the "outcome," the overall impact of parents' education on respondents' education. For each group, we calculate the outcome as the product of the amount of parental education (from the first row of numbers) and its effect on respondents' education (from the second row of numbers). ${ }^{34}$ We report the difference in outcomes between the relevant pairs of groups (between men and women, between Anglo Whites and Blacks, and between Anglo Whites and Latinos) in the last row. These numbers capture the extent to which group differences in the levels and/or effects of parents' education contribute to disparities between groups in respondent's education. The positive entries in the cells indicate that parents' education widens the gap between groups in respondent's education.

Notice that, in the first pair of columns, parents' education does not help to explain the gender gap in educational attainment. Although parental education is a significant 
Table 5

A. The Consequences of Parents' Education for Respondent's Education: An Outcomes Analysis

\begin{tabular}{|c|c|c|c|c|c|}
\hline & Men & Women & $\begin{array}{l}\text { Anglo } \\
\text { Whites }\end{array}$ & $\begin{array}{c}\text { African } \\
\text { Americans }\end{array}$ & Latinos \\
\hline Average level of parents' education & .23 & .22 & .23 & $.16^{\mathrm{a}}$ & $.13^{\mathrm{a}}$ \\
\hline Coefficient on parents' education & $.71^{* * *}$ & $.70^{* * *}$ & $.71^{* * *}$ & $.60^{* * *}$ & $.75^{* * *}$ \\
\hline \multirow[t]{3}{*}{ Overall outcome for group } & .16 & .16 & $.15(.17)^{\mathrm{b}}$ & .11 & .09 \\
\hline & & \multirow{2}{*}{\multicolumn{2}{|c|}{$\begin{array}{l}\text { Between Men } \\
\text { and Women }\end{array}$}} & \multicolumn{2}{|c|}{ Between Anglo Whites and: } \\
\hline & & & & frican Amer & ins Latinos \\
\hline \multicolumn{6}{|c|}{ Consequences for gap between groups in education } \\
\hline \multicolumn{2}{|c|}{ Differences between groups in outcomes } & \multicolumn{2}{|c|}{0} & .04 & .08 \\
\hline \multicolumn{6}{|c|}{ B. The Consequences of Parents' Education for Politics at Home: An Outcomes Analysis } \\
\hline & Men & Women & $\begin{array}{l}\text { Anglo } \\
\text { Whites }\end{array}$ & $\begin{array}{c}\text { African } \\
\text { Americans }\end{array}$ & Latinos \\
\hline Average level of parents' education & .23 & .22 & .23 & $.16^{\mathrm{a}}$ & $.13^{\mathrm{a}}$ \\
\hline Coefficient on parents' education & $.31^{* * *}$ & $.34^{* * *}$ & $.32^{* * *}$ & $.38^{* * *}$ & $.37^{* * *}$ \\
\hline \multirow[t]{3}{*}{ Overall impact for group } & .08 & .08 & .08 & .06 & .05 \\
\hline & & \multirow{2}{*}{\multicolumn{2}{|c|}{$\begin{array}{l}\text { Between Men } \\
\text { and Women }\end{array}$}} & \multicolumn{2}{|c|}{ Between Anglo Whites and: } \\
\hline & & & & frican Amer & Ins Latinos \\
\hline
\end{tabular}

Consequences for gap between groups in politics at home

$\begin{array}{llll}\text { Differences between groups in outcomes } & 0 & .02 & .03\end{array}$

Separate equations for women, men, Anglo Whites, African Americans, and Latinos, with age, age over 65, gender, race, and ethnicity in the equation. See Appendix A for parallel analyses using interaction terms.

* Coefficient significant at $\mathrm{p}<.05$.

** Coefficient significant at $\mathrm{p}<.01$.

*** Coefficient significant at $\mathrm{p}<.001$.

a Significantly different from Anglo Whites at $\mathrm{p}<.01$.

b .15 is calculated using the average coefficient for Anglo Whites and African Americans; .17 is calculated using the average coefficient for Anglo Whites and Latinos.

predictor of respondent's education for both women and men, there are no significant gender differences either in the average amount of parental education or in the impact of parental education on respondent's education. Hence, while the men in the sample are, on average, better educated than the women are, parental education plays no role in creating that educational difference. In contrast, disparities in parents' education do account for some of the educational differences between African Americans and Anglo Whites and, especially, between Latinos and Anglo Whites. In short, adult women, Blacks, and Latinos are all disadvantaged with respect to the single most important participatory factor, educational attainment; however, for the latter two groups the deficit has its origins, at least in part, in the lower levels of educational attainment within the previous generation while for women its sources are elsewhere.

Table 5B, which reports a parallel analysis for the effect of parental education on the likelihood that the respondent was exposed to political stimuli at home, contains analogous results. Once again, parental education has an impact, in this case, on political exposure. And, once again, the effect results from significant group differences in parents' education, rather than from any significant differences among groups in the magnitude of the impact 
Table 6

The Effects of Parents' Education on Inequality in Participatory Factors ${ }^{a}$

\begin{tabular}{lccc}
\hline & $\begin{array}{c}\text { Between Men } \\
\text { and Women }\end{array}$ & $\begin{array}{c}\text { Between Anglo Whites } \\
\text { and African Americans }\end{array}$ & $\begin{array}{c}\text { Between Anglo } \\
\text { Whites and Latinos }\end{array}$ \\
\hline $\begin{array}{c}\text { Effects of parent's education through } \\
\text { respondent's education and politics at } \\
\text { home on the gap in the acquisition of: }\end{array}$ & & & \\
Civic skills & 0 & +.01 & +.04 \\
Recruitment & 0 & -.01 & -.01 \\
Family income & 0 & 0 & +.01 \\
Additional effects of parents' education & & & 0 \\
on the gap in the acquisition of: & 0 & 0 & 0 \\
Civic skills & & 0 & 0 \\
Recruitment & +.02 & 0 & 0
\end{tabular}

a Positive entries indicate that parents' education has the effect of widening the gap between the groups; negative entries indicate that parents' education has the effect of narrowing the gap between groups.

of parental education. Group differences in parents' education explain, in part, the differences in the exposure to politics at home African Americans and Anglo Whites and between Latinos and Anglo Whites.

\section{The Acquisition of Other Participatory Factors}

The next step is to assess the impact of parental education on several key participatory factors: family income, civic skills, and requests for political activity. These participatory factors originate in adult institutions-the workplace, non-political organizations, and religious institutions. Parental education can affect the acquisition of these factors in either or both of two ways. First, those whose parents are well educated might be better positioned to acquire such factors. Such a direct effect would be indicated by a significant coefficient for parents' education on one or more of these participatory factors, even with the intermediate step of the respondent's own education taken into account. Second, we know that respondents whose parents are well educated are likely to be well educated themselves, and well-educated respondents are more likely to be able to stockpile these participatory factors.

The top section of Table 6, which examines various paths through which disparities in participatory factors are created, shows, for each of the groups, the effects of parental education on the acquisition of participatory factors-through its impact on respondent's education. We calculate these effects of parents' education by combining the coefficients for parents' education on respondent's education and the levels of parents' education (shown in Table 5A) with the coefficients for respondent's education from group-specific OLS regressions predicting the various participatory factors. ${ }^{35}$ Although parents' education has an impact on respondent's education, and respondent's education, in turn, has an impact on civic skills, recruitment to political activity, and family income, when these effects are multiplied together, the result is only a moderate impact on the disparities between groups in participatory factors. Not surprisingly, there are no effects on the gender difference in participatory factors. The gap between groups in parents education has a mixed and limited effect on 
Table 7

The Effects of Parents' Education on the Gap in Number of Political Acts

\begin{tabular}{|c|c|c|c|}
\hline & $\begin{array}{l}\text { Between Men } \\
\text { and Women }\end{array}$ & $\begin{array}{l}\text { Between Anglo-Whites } \\
\text { and African Americans }\end{array}$ & $\begin{array}{l}\text { Between Anglo- } \\
\text { Whites and Latinos }\end{array}$ \\
\hline \multicolumn{4}{|c|}{$\begin{array}{l}\text { Effects of parents' education } \\
\text { on the gap in participation through: }\end{array}$} \\
\hline Respondent's education & .00 & .06 & .09 \\
\hline Politics at home & .00 & .07 & .07 \\
\hline Family income & .004 & .02 & .04 \\
\hline Adult institutions & .03 & .00 & .04 \\
\hline $\begin{array}{l}\text { Additional effects of parents' educ } \\
\text { on the gap in participation }\end{array}$ & .00 & .17 & .17 \\
\hline $\begin{array}{l}\text { Total effects of parents' education } \\
\text { on the gap in participation }\end{array}$ & .034 & .32 & .41 \\
\hline Initial difference in participation & .31 & .32 & 1.09 \\
\hline
\end{tabular}

the disparity in such factors between African Americans and Anglo Whites-a small gain for Anglo Whites over Blacks in civic skills counterbalanced by a small gain for Blacks over Whites in recruitment. The most pronounced impact is the advantage in participatory factors accruing to Anglo Whites vis-à-vis Latinos, largely as the result of the additional civic skills the former develop by virtue of the impact of their parents' education on their own education. As shown in the bottom portion of Table 6, there are almost no additional effects of parental education - that is, through paths not considered here-on group differences in the acquisition of these participatory factors. ${ }^{36}$

\section{Parents' Education and Political Activity: Summing the Effects}

We are now in a position to combine these analyses in a summary measure of the effect of parental education on participatory inequality. Adopting an approach analogous to that used to estimate the various effects of parental education on the acquisition of participatory factors, we present data in Table 7 summarizing the implications of group differences in parents' education for disparities in participation between women and men, between Anglo Whites and Blacks, and between Anglo Whites and Latinos. ${ }^{37}$

The intergenerational impact of parental education has almost no role in the creation of gender differences in participation. It has only a modest indirect effect through adult institutions and no additional effects. In contrast, group differences in parents' education have, not unexpectedly, much more substantial consequences for participatory inequalities among Latinos, African Americans, and Anglo Whites. For both Blacks and Latinos, group differences in parental education play an important role in creating a participation gap with Anglo Whites. In both cases the effects that operate through the impact of parents' education on respondent's education are matched by additional effects of roughly equal magnitude. These effects are even more substantial for Latinos than for African Americans. However, since the disparity in activity between Anglo Whites and Latinos is more than three times as large as that between Anglo Whites and Blacks, the impact of parents' education on political activity accounts for a smaller proportion of the participation gap for Latinos than it does for Blacks. ${ }^{38}$ 
In short, while processes of intergenerational transmission operate across the board to create participatory inequalities among individuals, the implications of these processes in creating participatory inequalities among groups are quite different for gender than for race or ethnicity. Because boys and girls do not differ systematically in the education of their parents, processes of intergenerational transmission play almost no role in explaining why men are somewhat more politically active than women. ${ }^{39}$ In contrast, these process are crucial in explaining the participatory gap between Anglo Whites and Latinos or African Americans.

\section{Conclusion}

We began this paper by noting the contrasting interpretations that Americans bring to economic and political equalities. In the economic domain, so long as we compete on an equal footing, we expect that the fleet and the tenacious will fare better, and we accept massive inequalities of wealth and income. We are more egalitarian with respect to the political arena-believing that the promise of democracy is equal responsiveness to all citizens.

This paper has elucidated the extent to which these abstract principles are transgressed by the realities of economic and political life. Neither domain is characterized by equality of condition: we are unequal with respect to both income and, in violation of the commitment to the level playing field of democracy, political participation. Moreover, contrary to the promise of the American Dream, in neither domain does equality of opportunity obtain: the transmission of class advantage across generations implies that we are not even equal at the starting line. We have seen that in politics, just as in economics, the driving force behind intergenerational transmission of inequality is parents' education. Parental education has a potent impact on political activity because well-educated parents are more likely both to provide a politically rich environment and to have children who become well-educated, affluent adults. In turn, well-educated offspring are likely to be better off with respect to nearly every other participatory factor: to have challenging and financially rewarding jobs, to develop civic skills and to receive requests for participation in non-political institutions, to be politically informed and interested, and so on. ${ }^{40}$ Thus we have added to our understanding of the origins of political participation. Most of the proximate causes of political participation have their roots, at least in part, in social class background.

The processes by which initial class background influences subsequent political activity operate across individuals regardless of their other demographic characteristics. When we explored how these processes intersect with participatory inequalities among groups-between women and men and among African Americans, Latinos, and Anglo Whites-we found a complex and interesting pattern. On the one hand, there are no significant differences across groups defined by their gender or by their race or ethnicity in the way that the legacy of class origin is translated into political participation. That is, the effect of SES background on adult political activity does not vary either with gender or with race or ethnicity.

On the other hand, the intergenerational transmission of educational advantage plays a very different role in the creation of disparities in activity between groups defined by their gender than in the creation of participatory differences among groups defined by race or ethnicity. The gender gap in political participation is not a function of initial class differences. Men and women are born randomly into families across the SES spectrum. That men's average levels of educational attainment have traditionally surpassed women's reflects social processes and individual choices during childhood and adolescence-rather than any 
systematic difference in parents' education. The educational disparity between women and men is one of several factors - including men's advantage with respect to the kinds of jobs that provide civic skills and requests for political activity and the disproportionate representation of men among political leaders suggesting that politics is a man's world - that explain why men are somewhat more active in politics than women are. ${ }^{41}$

In sharp contrast, group differences in parents' education figure importantly in explaining participatory inequalities among Anglo Whites, Blacks, and Latinos. Class background plays a role from the beginning in the family of origin. Yet we must hasten to add that, in asserting that social class is the key to racial and ethnic differences in participation, we are not in any way claiming that race or ethnicity is irrelevant. On the contrary, class differences along racial or ethnic lines reflect the results of processes of discrimination that have everything to do with racial or ethnic status. It is hardly a coincidence that there are SES differences among racial and ethnic groups and that these racial and ethnic disparities in class background persist across generations. Thus, our argument depends not on distinguishing race or ethnicity, on the one hand, from class, on the other, but rather on the ways that these are inextricably mixed. Still, it is worth noting that, for African Americans and Latinos, the deficit in participation is handed down from generation to generation; for women, it is created anew throughout the life cycle.

\section{Acknowledgments}

We would like to thank Barb Opal and Jamina Campbell for help constructing the tables and DeAunderia Bryant for research assistance. We are grateful to the National Science Foundation, the Spencer Foundation, the Ford Foundation, and the Hewlett Foundation for their generous support in the gathering of the data.

\section{Notes}

1. On these themes, see Hochschild (1981, esp. chap. 6); McClosky and Zaller (1984, esp. chap. 3); and Verba and Orren (1985, chaps. 1, 8, and 9).

2. See, for example, Blau and Duncan (1967); Hauser and Featherman (1977); Hout, (1988); Ganzeboom, Treiman, and Ultee (1991); Solon (1992); McMurrer and Sawhill (1998); and Smelser, Wilson, and Mitchell (1999).

3. Among the analyses of political activity that demonstrate the connection between SES and political activity are Verba and Nie (1972); Wolfinger and Rosenstone (1980); and Rosenstone and Hansen (1993). In spite of its unambiguous empirical power, it is common to deride the "SES Model of Participation," as simplistic, apolitical, and atheoretical. See Leighley (1995, pp. 183-188) for a trenchant summary of the criticisms of the SES model. For a more theoretical presentation that explains the linkage between socioeconomic status and activity, see Verba, Schlozman, and Brady (1995).

4. On participatory differences among groups defined by their race or ethnicity, see, Verba and Nie (1972); Verba, Schlozman, Brady, and Nie (1993); Verba, Schlozman, and Brady (1995); Leighley and Vedlitz (1999); and Leighley (2001). On the participation gap between women and men, see Andersen (1975); Welch (1977); Beckwith (1986); and Burns, Schlozman, and Verba (2001).

5. In a review article written a third of a century ago, Jack Dennis (1968) was able to draw on an extensive bibliography of works about political socialization. Nevertheless, before even two decades had passed, Timothy Cook (1985, p. 1079) noted the decline in interest in political socialization remarking that "the bull market has turned bearish."

6. See, for example, Dawson and Prewitt (1969, chap. VII); and Jaros (1973, p. 80).

7. See, for example, Davies (1965); Greenstein (1965); Hess and Torney (1967); Easton and Dennis (1969); Jaros (1973, pp. 84-85); Jennings and Niemi (1974); Jennings and Niemi (1981); and Beck and Jennings (1991). Assessing the long series of political socialization studies that he and his associates have conducted, M. Kent Jennings (2000) points to the emphasis on partisanship and political preferences rather 
than on participation. Participation is treated more as an intervening variable in the process of intergenerational transmission of political orientations than as a dependent variable in its own right: active parents are more likely to pass on their political preferences to their offspring than are less active parents. More recently, important work uses longitudinal socialization studies to focus on the transmission of activity. See Jennings and Stoker (2001); and Campbell (2002).

8. See, for example, Greenstein (1965, chap. 5); Hess and Torney (1967, chaps. 5, 7); Chaffee, McLeod, and Wackman (1973); Jaros (1973, p.83); and Sigel and Brookes (1974, pp. 120-122).

9. In an article that focuses on the role of personality development in political socialization, Stanley Renshon (1975, pp. 47-50) comes close to suggesting this alternative mechanism for the translation of SES advantage into participatory advantage across generations. Without mentioning educational opportunities per $s e$, he argues (p. 48) that SES is "a shorthand for a whole range of life and developmental experiences, attitudes, and life-styles" and that a child who is born into a high SES family has the advantage of an "expanding choice system."

10. For an account of the factors that foster political activity and, in particular, the participatory consequences of educational attainment, see Verba, Schlozman, and Brady (1995, chap. 15). An additional reason for paying special attention to education is that we have better measures of parental education than of the other socio-economic characteristics of the family of origin.

11. For a discussion of politically relevant categories from the point of view of the representation of political interests, see Verba, Schlozman, and Brady (1995, chap. 6). We should also note that political activity depends heavily on political mobilization and the channels of mobilization are often group specific. See Rosenstone and Hansen (1993); and Verba, Schlozman, and Brady (1995).

12. We use data from the Citizen Participation Study, which was conducted in 1990. For wording of all questions and information about the survey, the oversamples of Latinos, African Americans, and those who are active in politics, and the characteristics that allow it to be treated as a national random sample, see Verba, Schlozman, and Brady (1995, Appendixes A and B). Because we are concerned with intergenerational processes, we considered using the Jennings and Niemi data, which have the unambiguous advantage of multiple studies of the same individuals over time. However, the oversamples of Latinos and African Americans in the Citizen Participation sample and the measures of civic skills and recruitment in the questionnaire make these data more appropriate for the questions we ask here.

13. The bivariate correlation between a scale of parental political involvement and respondent's activity is .20 $(\mathrm{p}<.001)$. For details about the variables used in this paper, see Appendix B.

14. We were concerned that the relationship between early exposure to politics at home and adult participation represented backward projection - with memories of the past colored by current commitments. Data about gender differences presented in Table 4 cast doubt on this interpretation. See footnote 30 and Table 4.

15. The bivariate correlation is .43 ( $\mathrm{p}<.001)$. Because educational attainment is so deeply influenced by birth cohort, here and elsewhere, we have corrected the measure of parents' education for age. See Appendix B.

16. The bivariate correlation is .26 ( $\mathrm{p}<.001)$.

17. For the measures of skills and requests for activity, see Appendix B.

18. With these factors taken into account, neither being African American nor being Latino is significantly associated with political activity. However, there is a small, though significant, relationship between participation and being male.

19. For details of this analysis, see Appendix B. Our work draws on and parallels the analyses of the effects of parents' education on status attainment in the literature on social mobility. (See, for example, Blau and Duncan, 1967). These early models made clear that "education is . . the main vehicle of social reproduction" (Ganzeboom, Treiman and Ultee, 1991, p. 284). We modify these earlier analyses by expanding the model to include women and incorporating mothers' educational level among the explanatory factors.

20. Until 1976 the National Election Studies asked about parents' levels of political interest. We used these data to explore the parental legacy of political involvement with results consistent with those presented here.

21. We assume that these additional effects reflect the operation of the unmeasured processes discussed earlier as well as the measurement error in our measures-in particular, the scale measuring home political environment.

22. The impact on contributions that we are assigning to parents' education could well be the result of their income, which is, of course, associated with their education. Unfortunately, the questionnaire included no information about parents' income.

23. See Verba, Schlozman, and Brady (1995, Chapter 6) and Burns, Schlozman, and Verba, (2001). The mean scores on the eight item scale are: Men 2.3, women 2.0 (Diff. sig .00); Anglo-Whites 2.1, African Americans 1.9; Latinos 1.2 (Diffs. between Anglo-Whites and the other two groups sig. .00).

24. Charles Tilly (1998, p. 6) makes clear that what he calls bounded categories deserve special attention 
because they provide clearer evidence for the operation of durable inequality, because their boundaries do crucial organizational work, and because categorical differences actually account for much of what ordinary observers take to be results of variation in individual talent or effort. On the importance of paying attention to categorical differences, see also Young (1994).

25. For earlier examples using outcomes analysis, see Stokes, Campbell, and Miller (1958) and Gilens (1988).

26. As in Table 1, parental education in measured as the age-adjusted average of mother's and father's educational attainment and home political environment is a scale composed of mother's and father's level of political activity and the frequency of political discussion at home at age 16. In Table 4, these scales, along with respondent's education and political activity, have been rescaled to vary from 0 to 1 .

27. Data from the General Social Survey, which include more precise information about the educational attainment of each parent, show that the difference between Whites and Blacks is a bit under three years of schooling (averaged for both parents) and between Anglo Whites and Latinos about five years.

28. Calculated from: census.gov/population/socdemo/education/table A-2.txt. Interpreting the narrowing of the educational gap requires caution. A higher proportion of African-American students than white students receive a GED which may have less educational value, and the quality of education may differ from one group to another with the increase in high school completion more often a function of social promotion (Jencks, 1992).

29. There are no comparable data for 1940. The decrease in the ratio is likely the result of recent immigration patterns that have changed the class composition of the Latino population.

30. The reports by men and women respondents about their parents' educational attainment and political involvement lend credence to our claim that these retrospective reports are not unduly contaminated by adult experience. If respondents were projecting backward, we would expect the advantage of male respondents with respect to both educational attainment and political participation to result in recollections of higher levels of educational attainment and political involvement for the parents of male respondents. Instead we find no differences in the reported educational level or political involvement of the parents of male and female respondents, a result consistent with the fact that women and men are born randomly into all kinds of families.

31. As noted previously, these variables have been rescaled to vary between 0 and 1 .

32. These equations include controls for age. In addition, the equations for men and women include controls for race or ethnicity, and the equations for Anglo Whites, African Americans, and Latinos contain controls for gender.

We have replicated these results with single-equation models and interaction terms for the groups we consider here. The results of those analyses yield conclusions identical to the conclusions we draw here. See Appendix A for these results. In the tables we report in the body of this paper, we use t-tests to assess the difference between the coefficients for the two groups. By these tests, none of these coefficients differ across groups. The same is true in the interactive models. We chose to use split samples here enable the reader to see the possibility of difference even more clearly than one would see it in an interactive model.

33. Although the difference between the coefficients for African Americans and Anglo Whites is not statistically significant, it is sufficiently large that we would expect to find substantive differences in larger samples. Longitudinal analysis of the association between the educational attainment of parents and their offspring shows the relationship seems to be stable for Whites but-reflecting the strides in educational attainment among Blacks in recent decades - a diminishing one for African Americans. See Jencks (1992, pp. 175-176).

On longitudinal changes in the intergenerational transmission of education for various groups, see Featherman and Hauser (1976a, 1976b, 1978); Hauser and Featherman (1977); Corcoran (1995).

34. See Appendix B for details of these calculations.

35. We calculated these effects exactly as we did in Table 2. See also Appendix B.

36. Using separate OLS regressions for each of the five groups and controlling for respondent's education, political exposure at home, and age, we find only one case in which there is a significant coefficient for parents' education. For women, higher levels of parental education decrease women's exposure to recruitment requests, a result that puzzles us. In this case, the effect of parents' education is to widen the gender gap with respect to an important participatory factor.

It is important to recognize that the figures in Table 6 do not tell the whole story of how group differences in participatory factors are created by differential processes of selection into and treatment in non-political institutions. Instead, they pertain only to that part of the group difference that results from the various effects of parents' education.

To reduce the amount of data we need to present, we have truncated the analysis somewhat. The acquisition of participatory factors in non-political institutions involves two stages: the process by which 
individuals choose to affiliate with an institution and the experiences individuals have once they are in the institution. While we have conducted these more elaborate analyses elsewhere, we chose to use a streamlined approach in this paper because of the number of groups we are considering.

37. See Appendix B for an explanation of the method used here.

38. To the extent possible, we replicated these analyses using the National Black Election Study and the Latino National Election Study with results consistent with those presented here. We also replicated the analysis using time-based acts and political contributions as dependent variables. For all five groups, parents' education has an impact on family income, above and beyond its impact on respondent's education, and for all five groups family income is overwhelmingly important in explaining political contributions. Thus, we confirm for women and men and for Latinos, African Americans, and Anglo Whites the earlier analysis showing multiple streams of influence of parental legacy.

In addition, in order to circumvent the oversimplification of assuming that men and women of the three race and ethnic groups (or that Whites or Blacks or Latinos of either sex) are essentially the same, we replicated this analysis for the six groups at the intersection of gender and race or ethnicity: Latinas, Latinos, African American women, African American men, Anglo-White women, and Anglo-White men. Our results were unchanged. While there are important differences among groups defined by their race or ethnicity in the role played by intergenerational transmission, there are no important differences in these processes for the men and women within any racial or ethnic group.

39. There might be other familial effects that are different for girls and boys, for which we do not have measures. For example, boys may receive different socialization cues about proper activities in later life.

40. As mentioned earlier, we have focused exclusively on parents' education because we have no information about their incomes or occupations. We would surmise that better information about these and other manifestations of class background would have strengthened our argument.

41. See Burns, Schlozman, and Verba (2001) for a full account of these processes.

\section{References}

Andersen, Kristi. 1975. "Working Women and Political Participation, 1952-1972." American Journal of Political Science 10: 439-55.

Beck, Paul Allen, and M. Kent Jennings. 1991. "Family Traditions, Political Periods, and the Development of Political Orientations." Journal of Politics 53: 742-763.

Beckwith, Karen. 1986. American Women and Political Participation. New York: Greenwood Press.

Blau, P.M., and O.D. Duncan. 1967. The American Occupational Structure. New York: Wiley.

Burns, Nancy, Kay Lehman Schlozman, and Sidney Verba. 2001. The Private Roots of Public Action: Gender, Inequality, and Political Participation. Cambridge: Harvard University Press.

Campbell, David. 2002. "Participation in Context: How Communities and Schools Shape Civic Engagement." Ph.D. Dissertation, Harvard University.

Chaffee, Steven H., Jack M. McLeod, and Daniel Wackman. 1973. "Mass Communication and Socialization." In Jack Dennis, (ed.), Socialization to Politics: A Reader. New York: John Wiley.

Cook, Timothy E. 1985. "The Bear Market in Political Socialization and the Costs of Misunderstood Psychological Theories." The American Political Science Review 79: 1079-1093.

Corcoran, Mary. 1995. "Rags to Rags: Poverty and Mobility in the United States." Annual Review of Sociology 21: 237-67.

Davies, James C. 1970. “The Family's Role in Political Socialization.” In Roberta S. Sigel, (ed.), Learning about Politics. New York: Random House.

Dawson, Richard E., and Kenneth Prewitt. 1969. Political Socialization. Boston: Little, Brown.

Dennis, Jack. 1968. "Major Problems of Political Socialization Research." Midwest Journal of Political Science 12: $85-114$.

Easton, David, and Jack Dennis. 1969. Children and the Political System: Origins of Political Legitimacy. New York: McGraw Hill.

Featherman, David L., and Rita M. Hauser. 1976a. "Changes in the Socioeconomic Stratification of the Races, 1962-1973." American Journal of Sociology 82: 621-651.

- 1976b. "Sexual Inequalities and Socioeconomic Achievement in the U.S., 1962-1973." American Sociological Review 41: 462-483.

. 1978. Opportunity and Change. New York: Academic Press.

Ganzeboom, Harry B.G., Danald J. Treiman, and Wout C. Ultee. 1991. "Comparative Intergenerational Stratification Research." Annual Review of Sociology 17: 277-302. 
Gilens, Martin. 1988. "Gender and Support for Reagan: A Comprehensive Model of Presidential Approval." American Journal of Political Science 32: 19-49.

Greenstein, Fred I. 1965. Children and Politics. New Haven: Yale University Press.

Hauser, Rita M., and David L. Featherman. 1977. The Process of Stratification. New York: Academic Press.

Hess, Robert D., and Judith V. Torney. 1968. The Development of Political Attitudes in Children. Anchor Books; Garden City, NY: Doubleday.

Hochschild, Jennifer. 1981. What's Fair?: American Beliefs about Distributive Justice. Cambridge: Harvard University Press.

Hout, Michael. 1988. "More Universalism, Less Structural Mobility”, American Journal of Sociology 93: 13581400.

Jaros, Dean. 1973. Socialization to Politics. New York: Praeger.

Jencks, Christopher. 1992. Rethinking Social Policy: Race, Poverty, and the Underclass. Cambridge: Harvard University Press.

Jennings, M. Kent. 2000. "Participation as Seen through the Lens of the Political Socialization Project", paper prepared for a Conference on Participation: Building a Research Agenda, Center for the Study of Democratic Politics, Princeton University, October 12-14, 2000.

Jennings, M. Kent, and Richard G. Niemi. 1974. The Political Character of Adolescence: The Influence of Family and Schools. Princeton: Princeton University Press.

- 1981. Generations and Politics: A Panel Study of Young Americans and their Parents. Princeton: Princeton University Press.

Jennings, M. Kent, and Laura Stoker, "Generations and Civic Engagement: A Longitudinal Multi-Generation Analysis." 2001. Paper Prepared for the American Political Science Annual Meeting, San Francisco.

Leighley, Jan E. 1995. "Attitudes, Opportunities and Incentives: A Field Essay on Political Participation." Political Research Quarterly 48: 181-209.

Leighley, Jan E. 2001. Strength in Numbers?: The Political Mobilization of Racial and Ethnic Minorities. Princeton, N.J.: Princeton University Press.

Leighley, Jan E., and Arnold Vedlitz. 1999. "Race, Ethnicity, and Political Participation: Competing Models and Contrasting Expectations." The Journal of Politics 61: 1092-1114.

McClosky, Herbert, and John Zaller. 1984. The American Ethos: Public Attitudes Toward Capitalism and Democracy. Cambridge: Harvard University Press.

McMurrer, Daniel P., and Isabel Sawhill. 1998. Getting Ahead: Economic and Social Mobility in America. Washington, DC: The Urban Institute Press.

Renshon, Stanley Allen. 1975. "The Role of Personality Development in Political Socialization.” In David C. Schwartz and Sandra Kenyon Schwartz, (eds.), New Directions in Socialization. New York: Free Press.

Rosenstone, Steven J. and John Mark Hansen, 1993. Mobilization, Participation, and Democracy in America New York: Macmillan.

Sigel, Roberta S., and Marilyn Brookes. 1974. "Becoming Critical about Politics.” In Richard G. Niemi, (ed.), The Politics of Future Citizens. San Francisco: Jossey-Bass.

Smelser, Neil J., William Julius Wilson, and Faith Mitchell, eds. 2001. America Becoming: Racial Trends and Their Consequences. Washington, DC: National Academy Press.

Solon, Gary. 1992. "Intergenerational Income Mobility in the United States.” The American Economic Review 82: 393-408.

Stokes, Donald E., Angus Campbell, and Warren E. Miller. 1958. "Components of Electoral Decision.” American Political Science Review 52: 367-387.

Tilly, Charles. 1998. Durable Inequality. Berkeley: University of California Press.

Verba, Sidney, and Norman H. Nie. 1972. Participation in America. New York: Harper Row.

Verba, Sidney, and Gary Orren. 1985. Equality in America: The View from the Top. Cambridge: Harvard University Press.

Verba, Sidney, Kay Lehman Schlozman, Henry E. Brady, and Norman H. Nie. 1993. "Race, Ethnicity, and Political Resources: Participation in the United States." British Journal of Political Science 23: 453-497.

Verba, Sidney, Kay Lehman Schlozman, and Henry E. Brady. 1995. Voice and Equality. Cambridge: Harvard University Press, 1995.

Welch, Susan. 1977. "Women as Political Animals? A Test of Some Explanations for Male-Female Political Participation Differences." American Journal of Political Science 21: 711-731.

Wolfinger, Raymond E., and Steven J. Rosenstone. 1980. Who Votes?. New Haven: Yale University Press.

Young, Iris Marion. 1994. "Gender as Seriality: Thinking about Women as a Social Collective." Signs 19: 713738.

Verba, Burns, and Schlozman 


\section{Appendix A}

Interactive models, of course, generate the same results as the separate models we use in our analyses. To satisfy readers on this point, we present the interactive models in this appendix. We prefer the models separating the groups so that we do not give undue weight to the largest group in our sample-Anglo Whites.

A. Interactive model predicting respondent's education on the basis of parent's education, controlling for age. Parallel to Table 5A.

\begin{tabular}{lcc}
\hline Variable & Coefficient & Standard error \\
\hline $\begin{array}{l}\text { Parents' education } \\
\text { White women* }\end{array}$ & $.72^{* * *}$ & .05 \\
$\quad$ Parents' education & -.02 & .06 \\
$\begin{array}{l}\text { African-American men* } \\
\quad \text { Parents' education }\end{array}$ & -.22 & .19 \\
African-American women* & & \\
$\quad$ Parents' education & -.07 & .15 \\
Latino* & & \\
$\quad$ Parents' education & -.11 & .22 \\
Latina* & & .19 \\
$\quad$ Parents' education & .10 & .02 \\
White women & -.01 & .004 \\
African-American men & -.01 & .03 \\
African-American women & $-.06^{*}$ & .05 \\
Latino & -.06 & .04 \\
Latina & $-.17^{* * *}$ & .02 \\
Age & $-.07^{* * *}$ & .02 \\
Age over 65 & $-.11^{* * *}$ & .02 \\
Constant & $.55^{* * *}$ & \\
Adjusted R-squared & .26 & \\
N & 2515 & \\
\hline
\end{tabular}

${ }^{*} \mathrm{p}<.05$

${ }^{* *} \mathrm{p}<.01$

*** $\mathrm{p}<.001$ 
B. Interactive model predicting parents' political discussion and political activity on the basis of parents' education, controlling for age. Parallel to Table 5B.

\begin{tabular}{lcc}
\hline Variable & Coefficient & Standard error \\
\hline $\begin{array}{l}\text { Parents' education } \\
\text { White women* }\end{array}$ & $.30^{* * *}$ & .04 \\
$\quad$ Parents' education & .03 & .05 \\
$\begin{array}{l}\text { African-American men* } \\
\quad \text { Parents' education }\end{array}$ & .10 & .15 \\
African-American women* & & \\
$\quad$ Parents' education & .06 & .12 \\
Latino* & & \\
$\quad$ Parents' education & -.06 & .18 \\
Latina* & & .16 \\
$\quad$ Parents' education & .16 & .01 \\
White women & -.00 & .03 \\
African-American men & .01 & .03 \\
African-American women & .003 & .04 \\
Latino & .002 & .03 \\
Latina & $-.06^{*}$ & .02 \\
Age & .02 & .02 \\
Age over 65 & .02 & .01 \\
Constant & $.16^{* * *}$ & \\
Adjusted R-squared & .07 & \\
N & & \\
* p & & \\
**.05 & & \\
*** p<.01 & &
\end{tabular}




\title{
Appendix B
}

\author{
Data, Measures, and Method
}

Data

We use data from the Citizen Participation Study, which was conducted in 1990. For wording of all questions and for additional information about the survey, its oversamples of Latinos and African-Americans, its oversamples of those who are active in politics, and the characteristics that allow it to be treated as a national random sample, see Verba, Schlozman, and Brady (1995, Appendixes A and B).

\section{Measures}

Activity. Throughout the paper we measure political activity by an eight-point summary scale that includes the following political acts: voting; working in a campaign; contributing to a campaign; contacting an official; taking part in a protest, march, or demonstration; being affiliated with an organization that takes stands in politics; being active in the local community; and serving as a volunteer on a local board.

The scale has a Cronbach's Alpha of 0.60. The individual items in the scale are weakly correlated: the average correlation between the items is .17. Thus, while the realized distribution does not appear to be perfectly Normally distributed, the realized distribution and the pattern of correlations reassure us that an ordinary least squares regression is the appropriate technique to use. This technique is, of course, especially useful because of its robustness. Small changes in data and specification do not yield different results as they might with less robust methods. For a sense of the consequences of these small correlations for the distribution of the data, we used three variables that were more strongly correlated than others in the scale: informal local activity, organizational involvement, and contributing money to campaigns. We calculated what percentage of our respondents would have done two or more of these three acts had these acts been completely independent of one another. If these acts had been independent of one another, $25 \%$ of the sample would have engaged in two or more of these three acts. In our data, with the small correlations between acts, $26 \%$ of our sample participated in two or more of these acts. The full distribution of the variable in our data is

\begin{tabular}{cc} 
Number of Acts & Percentage of Respondents \\
\hline 0 & $17 \%$ \\
1 & 26 \\
2 & 20 \\
3 & 17 \\
4 & 11 \\
5 & 6 \\
6 & 2 \\
7 & 1 \\
8 & 0.1 \\
\hline
\end{tabular}

These are not, then, especially rare or especially correlated events; therefore, a Poisson or Negative Binomial specification would be inappropriate here. 
Explanatory variables. In order to facilitate comparisons across different independent variables that are measured in different metrics and that have different ranges, in Table 1 and other multivariate analyses we have transformed the independent variables to have a range from 0 to 1 .

Politics at home. We measure exposure to politics at home as the sum of the respondent's mother's political activity, the respondent's father's political activity, and the level of political discussion at home when the respondent was 16 years old and divide respondents into quartiles based on this scale. For each quartile, we show the proportion who undertook at least one of the seven political activities other than voting.

Parents' education. We measure parents' education as the average of the respondent's report of mother's education and father's education. There are missing data on parents' education and on the variables that compose politics at home. We worked extensively with these measures to ensure that using the average value to fill the missings does not change the results in any way. This is the appropriate place to fill these missing data. In addition, one might think that we should use the highest educated parent's education as our measure of parents' education. We think not. First, the results using both measures are identical. Second, standard measurement theory suggests that two measures deal with measurement error better than one, and so we rely on the average here.

For our comparisons to be informative, we need to take account of the fact that older parental generations have, on average, lower levels of education than younger ones do. To address that complication, throughout our analysis, we use an age-adjusted measure of parental education that measures the respondent's parents' education relative to the average educational level at the time. Thus, the assignment into quintiles reflects both the average of mother's and father's education and the educational distribution in the parental age cohort.

Civic skills. We measured civic skills by asking whether, in the past six months, the respondent wrote a letter, went to a meeting where she took part in making decisions, planned or chaired a meeting, or gave a presentation or speech in three separate adult institutions: the workplace, religious institutions, and non-political organizations. We asked these questions separately for each institution. The variable we use is the sum of the number of skills practiced in these three institutions.

Institutional recruitment. Similarly, our measure of requests for political activity is about requests originating in each of these three non-political institutions. We asked whether, in the last five years, the respondent was asked by the organization or its leaders, by the religious institution or its leaders, the workplace or the respondent's superiors to vote for or against certain candidates in an election for public office or take some other action on a local or national political issue-sign a petition, write a letter, go to a meeting, attend a protest or march, or get in touch with a public official. The measure of recruitment sums these requests across these three institutions.

Age. We have included two variables measuring age-the age in decades and whether the respondent is older than 65-as controls. This accounts for the curvilinear relationship of age to participation in a way that's easier on the reader than the squared terms that generate a parabolic specification.

\section{Method}

Table 2. We calculate the effects of parental education by multiplying the effects of parental education on intervening variables in the chain of analyses by the effects of these intervening variables on participation. While one might imagine using a traditional path 
analysis here, we prefer the increased amount of information available through the procedure we use here. We are especially keen to keep the actual units of our variables in plain view. Our method does that, while path analysis, with its reliance on standardization, does not.

To calculate the first five rows in the table, we estimated multivariate models of the impact of parents' education on politics at home, respondent's education, family income, civic skills, and recruitment. We multiplied the average level of parents' education by the coefficients on parents' education in those models to arrive at the amount of these variables due directly to parents' education. On average, respondents receive a direct boost of .07 to politics at home, .15 to education, .03 to family income, .04 to civic skills, and .01 to recruitment from their parents' education. We took those levels of skills and the like that were consequences of parents' education and multiplied them by the coefficients on those variables in Table 1 to calculate the indirect effect of parents' education on respondent's levels of participation via these five variables. For example, respondents receive an average boost to their own education of about .15 (on the 0 to 1 education scale) from their parents' education. We multiplied that .15 by the coefficient on education in the participation equation we reported in Table 1 (1.32) to arrive at an effect of .20 acts of participation resulting from the impact of parents' education on participation respondent's education.

To calculate the additional effects of parents' education (that is, the effects not operating through the paths we just outlined), we multiplied the average level of parents' education (.22 on a $0-1$ scale) by the coefficient on parents' education in Table $1(.22 \infty .61)$ to arrive at an additional effect of parents' education on adult political participation of .13 acts. This number represents the average additional effect of parents' education.

Table 5. Where there is no statistically significant difference between the groups in either the level or the effect, we use the average for both groups in calculating these products. Thus, in Table 5A, we use different levels $(.23$ and .13$)$, but the same effect $\left(\left(.5^{*}(.71+.75)\right)\right.$ $=.73)$ to show-for Anglo Whites and Latinos respectively-the consequences of parents' education for respondent's education. This strategy avoids privileging the largest groupAnglo Whites-in defining the average, as we would do if we simply calculated the average for the entire sample as an interactive model would do.

Table 6. We calculated these effects exactly as we did in Table 2.

To calculate the effects of parents' education, we combined our earlier analyses of the impact of parents' education on respondent's education and on politics at home. We paired the results of those earlier outcomes analyses - which made clear the precise consequences of parents' education for education and politics at home-with the coefficients in the equations predicting skills, recruitment, and family income. We first calculated the parts of the respondent's education and politics at home due to parents' education. Then, we took the part of education and politics at home due to parents' education and multiplied that by the coefficients on these two variables in the equations predicting civic skills, recruitment, and family income. The consequence was the boost in civic skills, recruitment, and family income that comes directly from the increases in politics at home and respondent's education that are due to parent's education. The notion, then, is that parent's education works indirectly-by creating education and politics at home-to generate skills, recruitment, and family income. The numbers we report here are the differences in the results of this process for the groups in question.

To calculate the additional effects of parents' education, we first estimated equations predicting civic skills, recruitment, and family income. These equations included parents' education, along with politics at home, education, marriage, preschool children, school- 
aged children, age, age over 65, gender, race, and ethnicity. We estimated these equations separately for women, men, Anglo Whites, African Americans, and Latinos. With the coefficients on parents' education in hand, we could calculate the direct effect of parents' education exactly as we did in the outcomes analyses we reported earlier. That is, we multiplied the coefficients on parents' education by the average level of parents' education for the group to yield the amount of theresource due to parents' education. Then we calculated the differences in these amounts of resources for the groups we examine here.

The results reported in Table 6 suggest that parents' education works to shape group differences indirectly, by affecting respondent's education and politics at home first.

Table 7. To calculate the numbers in Table 7, we extended the method used in Tables 2 and 6. First, we estimated equations predicting respondents' education, politics at home, family income, civic skills, and recruitment. Then, we used the coefficients from these models, in conjunction with the average level of parents' education to which the group had access, to calculate the predicted amount of education, politics at home, family income, civic skills, and recruitment due to parents' education. At that point, we had in hand the level of each of the participatory factors to which each of the five groups had access as a consequence of parents' education. We then estimated an equation predicting political participation. That equation yielded the coefficients to multiply by the levels of the factors due to parents' education. We, then, multiplied the two; the result was the amount of participation due to a particular path through which parents' education comes to shape respondents' political activity. Once we had that result, we calculated the net contribution to the gap in political action created through that path. 